\title{
Teachers at the Center: Place and Education Displacement in Southwest Atlanta
}

Thais Council, Georgia State University

Shaeroya Earls, Georgia State University

Shakale George, Georgia State University

Rebecca Graham, Georgia State University

Thais Council is a graduate of Georgia State University, College and Human Development where she earned a PhD in Educational Policy Studies with a Social Foundations concentration. Her research interests include participatory action research, critical literacy, and the Black experience.

Shae Earls is an educator and advocate from Southwest Atlanta. She is a doctoral student at Georgia State University in the Department of Educational Policy Studies. As a graduate of Booker T. Washington High School in Atlanta, she is passionate about serving and uplifting voices in her community and those like it.

Shakale George has worked in public education for the past 15 years. Her passion for all things education and advocacy compels Shakale to regularly convene a teacher book club to address social and cultural issues in education in an effort to promote equity in schools.

Rebecca Graham is an Assistant Principal at a charter school in Atlanta Public Schools. She grew up outside of Atlanta and witnessed White flight, and the effects of displacement on families and communities. Rebecca conducts research with a team of educators about gentrification in Southwest Atlanta.

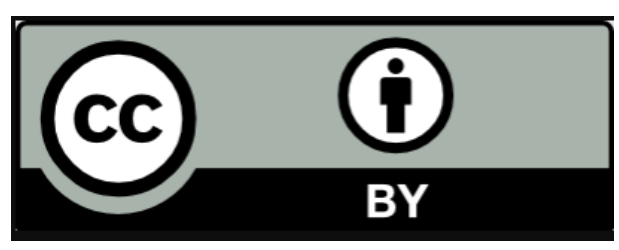

See: creativecommons.org/licenses/by/4.0/ 


\begin{abstract}
In Southwest Atlanta, urban education reform and gentrification have intersected to create the perfect collision of housing and educational displacement of Black students, Black families, and Black teachers. While Black communities are dealing with the impacts of gentrification, Black schools are simultaneously witnessing shifts that uproot students and their teachers. As a teacher participatory action research (PAR) collective, we share our personal experiences of housing displacement and how it has impacted our students, our communities, and our ability to maintain our positions as community-centered teachers. In this article, we acclimate readers to Atlanta, Georgia, and the Southwest Atlanta region in which we serve. We also illustrate how we have confronted the displacement of our students and ourselves. Finally, we highlight the significance of community-centered teachers operating within a Critical Studyin' for Human Freedom praxis in the struggle against systemic inequities that persistently plague our students and communities.
\end{abstract}

Keywords: community-centered teachers, gentrification, urban education reform 


\title{
Teachers at the Center: Place and Education Displacement in Southwest Atlanta
}

\author{
Thais Council, Georgia State University \\ Shaeroya Earls, Georgia State University \\ Shakale George, Georgia State University \\ Rebecca Graham, Georgia State University
}

In April 2015, 11 Black, Atlanta Public School educators were handed a guilty verdict on federal racketeering charges by Judge Jerry Baxter, who wailed that they "take no responsibility" for their students' achievement. The Black faces plastered across news programs and newspapers provided education reformers with faces to pin the complexities of public education. To those not familiar with the inner workings of public education, the guilty verdict implied that Black teachers are the problem of urban education and are criminals who must be locked away in order to save the most vulnerable children. The imagery of the Atlanta Cheating Scandal has paved the way for not only urban education reform to flourish, but also for the gentrification of Atlanta, Georgia. Both urban education reform and the gentrification of Atlanta, Georgia have displaced Black students, Black families, and Black teachers.

In this article, we offer a counternarrative (Matsuda, 1995) to the one thrust into the public and referred to as the Atlanta Cheating Scandal. Our counternarrative offers a new narrative in which Black teachers are not criminals or the problem of urban education. Instead, Black teachers are at the center, performing in ways that are in direct opposition to Judge Baxter's claim. In actuality, Black teachers are "taking responsibility" by working in the institutions that have taken over traditional schools, while also experiencing the menacing effects of gentrification. Black educators are taking responsibility by holding schools and communities together where local, state, and federal policy tore them apart through high-stakes testing, scripted and historically inaccurate curriculum, and high surveillance. Our professional lives and identities as Black and social justice teachers reject Judge Baxter's notion that Black teachers "take no responsibility" for student achievement. Not only do we take responsibility for Black student achievement, we also attend to the whole child, understanding that an urban education reform agenda does little to repair the long-standing damage inflicted upon Black students, families, and communities through race-based policy and practices. Black teachers are doing double duty by providing instruction and opportunities that equip students with academic and life skills while adding to students' academic and social identities in neighborhoods and schools that consistently remind them of structural failures.

In this article, we define displacement broadly as deliberately uprooting and dispossessing one community to make space for a different community. We attempt to show how urban education reform and gentrification are intricately connected, spun into one thread, and deceptively woven throughout the fabric of the city. This fabric is a Whiter, more affluent one where new residents quickly displace Black students, Black families, and Black teachers in neighborhoods and schools.

While we know that gentrification and urban education reform are not exclusive to Atlanta, Georgia, the city serves as a scheme for public school districts and neighborhoods with similar demographics. Morris \& Moore (2009) argue that the South as a research site is pivotal to understanding education nationally as most Black students in America reside in the South. Equally, Atlanta housing programs have been a beacon for urban cities across America and has long been the test site for housing projects. Vale (2013) calls Atlanta a "twice-cleared community" because of the persistent and historic displacement of Black communities twice on 
the same land. The first housing project in the United States was Techwood Housing projects originally constructed for White working-class residents (Holliman, 2008) and later, in the 1990s, again cleared of Black and poor residents for the HOPE VI project in preparation of the 1996 Centennial Olympics (Vale, 2013). When these two factors collide-education and housing-you have a model that is rife with inequities aimed directly at Black students, Black teachers, and Black communities.

In this paper, we share our experiences of housing displacement and how it has impacted our students. We are at the center of the fight to not only maintain stability for our students and communities, but also our right to remain as Black teachers and teachers with a social justice lens in rapidly changing neighborhoods and schools. Urban education reform and gentrification have spread widely across many urban centers in America. Our paper stands in solidarity with Black and social justice educators across the nation doing this necessary and often uncelebrated work of being the glue for so many broken parts of our schools and communities. In this article, we offer the story of Black and social justice teachers in urban education, and we intend for our paper to spark discussions about the role of educators, impactful community engagement and, more specifically, preparing teachers for social action.

We introduce readers to the theoretical framework that guided our work-Critical Studyin' for Human Freedom - as well as the participatory action research (PAR) approach we used throughout our work. We organized the remainder of the article into three parts: Part I acclimates readers to Atlanta, Georgia and a Southwest Atlanta, Georgia neighborhood. It illustrates how urban education reform and gentrification intersect to create the perfect collision of housing and educational displacement of Black students, Black families, and Black teachers. Part II depicts our personal experiences as teachers at the center of displacement and how we "take responsibility" of our students. Part III details the ways we work to confront displacement. We conclude our paper with a commitment to continue to raise our voices against systemic inequities that persistently plague our students and communities.

\section{Critical Studyin' and Teacher Participatory Action Research}

We_Thais, Shaeroya "Shae," Shakale, and Rebecca - are a participatory action research (PAR) collective. We are four educators, three who are Black women and one Jewish-American woman, who have equally dedicated and advocated our careers to urban education with more than 40 years of teaching experience combined. We grew up in similar surroundings as our students and experienced similar challenges, so we strive to create and maintain more equitable, robust educational experiences that will propel our students into opportunities they may not have

accessed otherwise. We operate within a community-centered teaching frame and are very close to the students, families, and stakeholders in our community. To this end, our work as a PAR collective is grounded in a "Critical Studyin' for Human Freedom" framework (King, 2006). Critical Studyin' means engaging in a way that is "cognitively and emotionally free of ideological constraints on knowledge, thought, and morally engaged action and pedagogy" (King, 2006, p. 338). Simply stated, we embody Critical Studyin' for Human Freedom first through our community-centered, humanistic, asset-based views of our Black students and the communities in which they live. Secondly, we believe our communities are a valid and trusted source of expertise and power, and we privilege their experiences in our teaching practices and through our research. We approach our students and communities through this lens, and our work aims to advance and honor their power. 
Participatory action research is an approach that privileges the experiences of those closest to an issue (Cahill, 2007). PAR emphasizes first understanding the world through conscious reflection, and then seeking collaborative ways to change it. In a PAR study, participants serve as co-researchers committed to equitable collective participation and social action (Valenzuela, 2016). Our PAR collective operates through a double aim (Fals Borda, 2001; McTaggart, 1997). A double aim seeks to both produce knowledge directly useful for those impacted and to shape the consciousness of researchers examining the issues. The double aim of our work also illuminates our position as marginalized by association (Stapleton, 2018). Our role as teachers makes us vulnerable and consequently blamed for urban education problems as enactors of education policy that excludes us from decision-making. As a result, we are learning and fighting simultaneously while educating students who are overwhelmed with complex structural issues and marginalized by the institutions intended to provide educational and social assurances.

Our Critical Studyin' started through a book club organized by Shakale. She coordinated book clubs on critical topics that were not discussed during professional development or inservice offerings. For two years, we have met biweekly on Saturday mornings to watch documentaries, read articles, and unpack our own misunderstandings about inequality in urban schools and society. After reviewing transcripts of our discussions and discussing the shifts in our understanding, we discovered that we embody many of the principles that constitute community-centered teaching: we live near our students, shop at the same stores as our students, participate in their extra-curricular activities, attend their family functions, include their parents in our classroom decisions, and advocate for them on all fronts.

As we began to problem-pose (Freire, 1970/1993), discussing issues and possible solutions surrounding inequity in education, a glaring problem presented itself when our students started leaving our schools, never to return. As community-centered educators dedicated to human freedom, we found it difficult to maintain connections or relationships with students and families due to increasing transience in our schools. We asked ourselves, "What is forcing our students to withdraw from school, and where are they going?" This question compelled us to confront and delve into gentrification and urban education reform surrounding us.

During our PAR sessions, we examined how the two mechanisms that are touted as building pathways to the American Dream, quality education, and homeownership, instead displace our students and their families. We read books and scholarly articles, analyzed local and state data, conducted community listening exchanges, and presented at regional and national conferences, one of which was an education conference for pre- and in-service teachers. Our conference presentations helped us to share and gain knowledge as well as listen to how local and national communities are disrupted by urban education reform and gentrification. Because we were witnessing the results of systemic economic and educational inequities firsthand in our schools and neighborhoods, we could no longer confine ourselves to our classrooms and ignore the effect that displacement was having on our schools and communities. Therefore, our Critical Studyin' brought us to use our collective energy, expertise, and talents to not only highlight this issue but also serve as a way to "take responsibility" for our students and communities. We did not embark on this task lightly. We were painfully aware of Georgia as an employment at will state $^{1}$ and consistently teetered on the edge of activism and maintaining employment, keeping in

\footnotetext{
${ }^{1}$ Georgia recognizes the doctrine of employment at will. Employment at will means that in the absence of a written contract of employment for a defined duration, an employer may terminate an employee for good cause, bad cause, or no cause at all, so long as it is not an illegal cause (Georgia Secretary of State, sos.ga.gov/index.php/corporations/what_georgia-employers_need_to_know).
} 
mind our livelihoods and the economic well-being of our families. We engaged in a way that positioned us as a resource for change in our schools and communities.

\section{Part I: Place, Urban Education Reform, \& Displacement in Southwest Atlanta, Georgia}

\section{Atlanta, Georgia}

Atlanta, Georgia, is one of the largest metropolises in the Southeastern United States. Once nicknamed Terminus because it marked the end of the Western \& Atlantic railroad, Atlanta has swelled into an international city that attracts professionals, technology entrepreneurs, entertainment and music artists, and a slew of college students each academic year. Atlanta politicians have billed Atlanta as "A City Too Busy to Hate" because of the number of civil rights legends that call Atlanta home and the subsequent number of organizations dedicated to the civil rights struggle. Atlanta is also affectionately known as the "Black Mecca" because of the vast number of Black professionals, politicians, entrepreneurs, and college graduates that take residence in the city.

Amidst these historical facts, a recent Bloomberg analysis listed Atlanta, Georgia, as having the highest level of income inequality in all U.S. cities. While several Fortune 500 companies are headquartered in Atlanta, the poverty rate is $24 \%$, with many people working lowpaying jobs in the hospitality, retail, and service industries (Foster \& Lu, 2018). Black residents comprise the lowest number of owner-occupant homes (Keenan, 2019), and this disparity is likely to increase with the wave of gentrification Atlanta is experiencing. Southwest Atlanta is the quadrant of the city where income inequality, poverty, gentrification, Black homeownership disparities are compounded.

\section{Housing Displacement in Southwest Atlanta, Georgia}

Southwest Atlanta is an area of the city that birthed many civil rights icons. Many of the highways, streets, and educational institutions bear their names: Ralph David Abernathy Boulevard, Joseph E. Lowery Boulevard, James E. Boone Boulevard, Maynard Jackson High School, and Coretta Scott King Young Women's Leadership Academy. Southwest Atlanta is also home to the Atlanta University Center (AUC) comprising four historically Black higher education institutions: Morehouse College, Spelman College, Clark Atlanta University, and Morris Brown College. Southwest Atlanta also houses the Mercedes Benz Stadium (which displaced a historic Black church) and is also close to the busiest airport in the country, Hartsfield-Jackson Atlanta International Airport.

In 2014, Southwest Atlanta experienced an $80 \%$ spike in home purchases within a halfmile of the city-funded Atlanta BeltLine (Lartey, 2018). The Atlanta BeltLine is a development project that connects 45 Atlanta neighborhoods through a 22-mile inactive railroad loop that encircles the city. The BeltLine offers retail, restaurant, recreation, and nightlife options to residents and visitors. The Atlanta BeltLine is the brainchild and senior thesis project of Georgia Institute of Technology graduate Ryan Gravel. Gravel's original intent of the Atlanta BeltLine was a grassroots commitment to use "transit as an infrastructure tool to encourage economic development in Atlanta's intown neighborhoods" (Gravel, 2005, p. 2). In essence, Gravel intended for long-standing communities to benefit from the increased economic development of the BeltLine. To the contrary, most of the home purchases in Southwest Atlanta are made by White newcomers and outside investors. The Atlanta BeltLine is the driver of gentrification in 
Southwest Atlanta (Housing Justice League and Research Action Cooperative, 2017) and has led to the educational displacement of both students and teachers.

\section{Urban Education Reform in Southwest Atlanta}

Southwest Atlanta houses many of the schools implicated in the sensationalized Atlanta cheating scandal. In 2009, the Atlanta Journal-Constitution (AJC) published an article claiming that several Atlanta Public Schools (APS) had high erasure marks and improbable gains on the statewide annual Criterion-Referenced Competency Test (CRCT), an assessment that measures academic proficiency and growth in English and Math for third through eighth graders. The AJC article prompted the Georgia Bureau of Investigations to launch an investigation into possible cheating and test tampering. What ensued was a media spectacle that entrapped 35 educators, testing coordinators, administrators, and former APS superintendent Dr. Beverly Hall into a lengthy legal battle that played out on American television screens (Royal \& Seriki, 2018). All 35 of the indicted educators were Black, and 11 received prison sentences (Robinson \& Simonton, 2019). In hindsight, this event can be identified as the catalyst for justifying the takeover of public schools in Southwest Atlanta.

In 2015, Governor Nathan Deal proposed an Opportunity School District (OSD) modeled after the Recovery School District in Louisiana and the Achievement School District in Tennessee designed to lift students out poverty (Office of Governor Nathan Deal, 2015). The OSD would have closed or turned over up to 100 failing schools to charter management organizations. In addition, OSD would have given the governor authority to appoint a superintendent who would not report to or consult with a local school board to make decisions. Money to fund an OSD would have come from already strapped public school funding.

The OSD was voted down two-to-one by Georgia voters during the 2016 election cycle. However, APS Superintendent Dr. Meria Carstarphen, who was accused in her former district of pushing a "corporate-reform-backed agenda" (Niesse, 2014, para. 4), continued to move forward with an APS Turnaround strategy. In 2014, Carstarphen worked with school stakeholders to create a strategic plan to support some of the lowest-performing schools in the district, many of which are schools in historically Black, disenfranchised, low-income neighborhoods in Southwest Atlanta. This initiative closed several public schools and turned them over to charter management organizations (such as Purpose Built Schools of Atlanta, KIPP, and Kindezi) through the disguise of improving achievement and school choice. To add insult to injury, these charter management organizations notoriously hired inexperienced, White teachers through programs such as Teach for America and the New Teacher Project to fill their school ranks. Most of the schools closed or turned over are located along the BeltLine corridor and/or were involved in the Atlanta Cheating Scandal.

Urban education reform in Atlanta Public Schools, as presented above, does not serve Black, historically disenfranchised students in Southwest Atlanta and does not lift students out of poverty as Governor Deal claimed an OSD would accomplish. These reforms are politics as usual by a different name while still not providing Black students with quality and equitable opportunities. Contrary to Judge Baxter's assertion of Black educators "taking no responsibility" for student achievement, the urban education reform and gentrification projects do nothing to take responsibility for years of structural racism, defunding of public education, and systemic inequities. The housing and educational displacement Southwest Atlanta students experience disrupts two mechanisms that Americans trust to boost economic and educational mobility: quality education and homeownership. 
We argue that urban education reform actually displaces Black students and their teachers, leading them and their families along unpromising paths with less access to choice and opportunities. Several schools in Southwest Atlanta have recently been modernized or are currently undergoing renovation for 21 st-century teaching and learning to add to the appeal of now highly sought-after real estate (Lareau \& Goyette, 2014). The students who have suffered the most from disinvestment in Southwest Atlanta schools will not benefit from these improvements but will be displaced instead.

The influx of newcomers, who are not connected to the culture and history of Southwest Atlanta, impact the mobility rates of Black students in the area. During one of our listening sessions, newcomers discussed how they are reluctant to enroll their children in neighborhood schools and instead opt for privately run schools, homeschooling, or other nontraditional schooling models. Their enrollment decisions, in turn, decrease funding for neighborhood public schools. Long-standing residents, then, are not only contending with fewer affordable housing options but are also dealing with the consequences of funds being plucked from already underfunded schools. Figure 1 depicts the mobility rate percentages of one Southwest Atlanta elementary school compared to the district percentage. Unsurprisingly, from 2014-2017, 40\% or more of the students who start each school year at this particular Southwest Atlanta elementary school did not finish the school year at the same school.

\section{Figure 1}

Southwest Atlanta Elementary School Mobility Rate

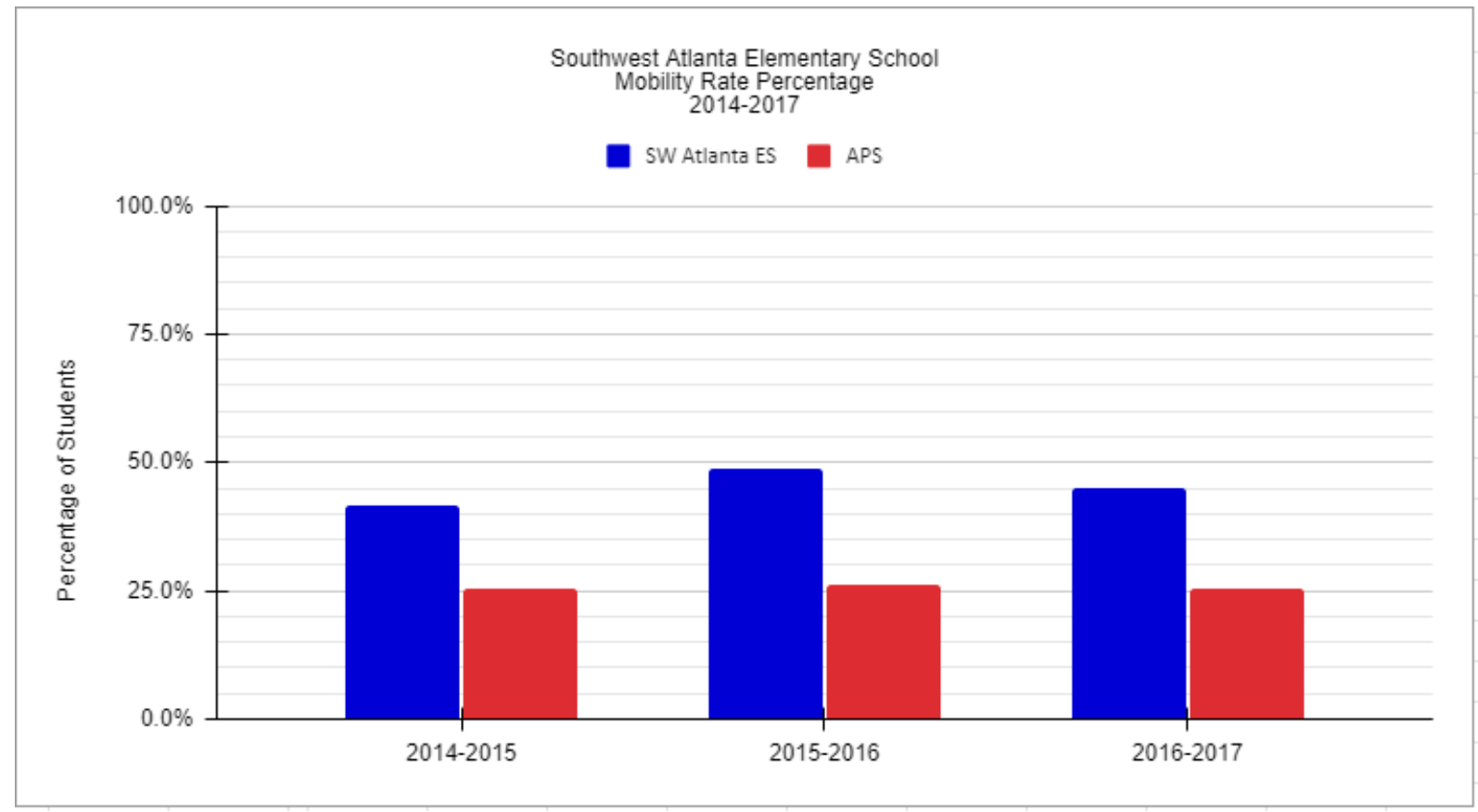

Note: Source: Governor's Office of Student Achievement. (2017), gosa.georgia.gov

High rates of mobility lead to children being stripped away from their generational networks and into spaces where there are limited community ties. As teachers in areas that are traditionally disenfranchised, we understand the importance of community and personal connection. When our students leave us and the community, the reassuring hugs in the hallway, 
invitations to birthday parties and sporting events, and impromptu parent-teacher conferences at the grocery store stay behind. The relationships and mutual trust we build with students and families we serve often lead to better overall educational experiences for kids. The most transient students often struggle to form connections with teachers and peers and may also lead to academic deficits (Alliance to Reclaim our Schools, 2015).

\section{Part II: Teachers at the Center of Displacement in Southwest Atlanta}

Each member of our PAR collective has a unique background intimately connected to education and housing in Southwest Atlanta. Rebecca is an Assistant Principal at a charter school in a quickly gentrifying neighborhood in Southwest Atlanta. She is the daughter of a 30-year education veteran who, during White flight, opted to stay in her metropolitan Atlanta neighborhood. Shakale is an Atlanta native and the daughter of a veteran educator. Although she works in Southwest Atlanta, her first-time home purchase was well outside the city limits of Atlanta because of limited housing stock and lack of affordability. Thais experienced pushout when she complained for months of unsanitary living conditions that the landlord was responsible for correcting. Afterward, the landlord refused to offer a lease renewal on a Southwest Atlanta home and, five months later, terminated the month-to-month agreement in the midst of her graduate studies at nearby Georgia State University. Shae, a Southwest Atlanta native and a teacher at a public charter school in the same area, grew up in Mozley Park - a historically Black neighborhood close to the Atlanta University Center. She is also a graduate of Booker T. Washington High School, a Southwest Atlanta neighborhood school with community pride and tradition. To show how we as teachers are not only countering displacement through our professional and nurturing actions but also dealing with gentrification on a personal level, we are privileging Shae's story to share the extent of place and displacement among Black families and communities in Southwest Atlanta. Shae shared,

I was taught that purchasing a house is one way for families to build and maintain wealth. However, when your family is victimized and taken advantage of with predatory loans, second mortgages, and interest rates, the American dream is more like a nightmare. My great-grandmother purchased a home in the small, predominantly Black Mozley Park neighborhood on the westside of Atlanta in 1995. This house was the family space, housing more than 3 generations. I moved from place to place often growing up in the city of Atlanta, but when I tell people I'm from the west side, some of my most vivid memories come from my days in this neighborhood. At the time of her death in 2017, my great-grandmother still owed $\$ 59,000$ on a house that cost $\$ 55,000$ when she purchased it more than 22 years ago (see Figure 2). Now, in 2019, the house is on the market for $\$ 299,000$ after being bought and flipped by a real estate investor (see Figure 2). This house was not just any house. This house raised me. My family went through many stages of homelessness where we bounced from floors to couches in the homes of various 
friends and family members, but this house was always our stability. When my mother made the decision to keep our school and community network consistent despite our financial hardships, this house was the address that allowed those connections to remain. When my great-grandmother passed, we were left with a roach-infested, dilapidated house that was going into foreclosure. It was easy for someone to purchase the house, knock down a few walls, slap some paint on it, and make a huge profit. People will say the house was empty and it didn't matter, but it did matter to us.

\section{Figure 2}

Shae's Childhood Family Home in Mozley Park, Atlanta
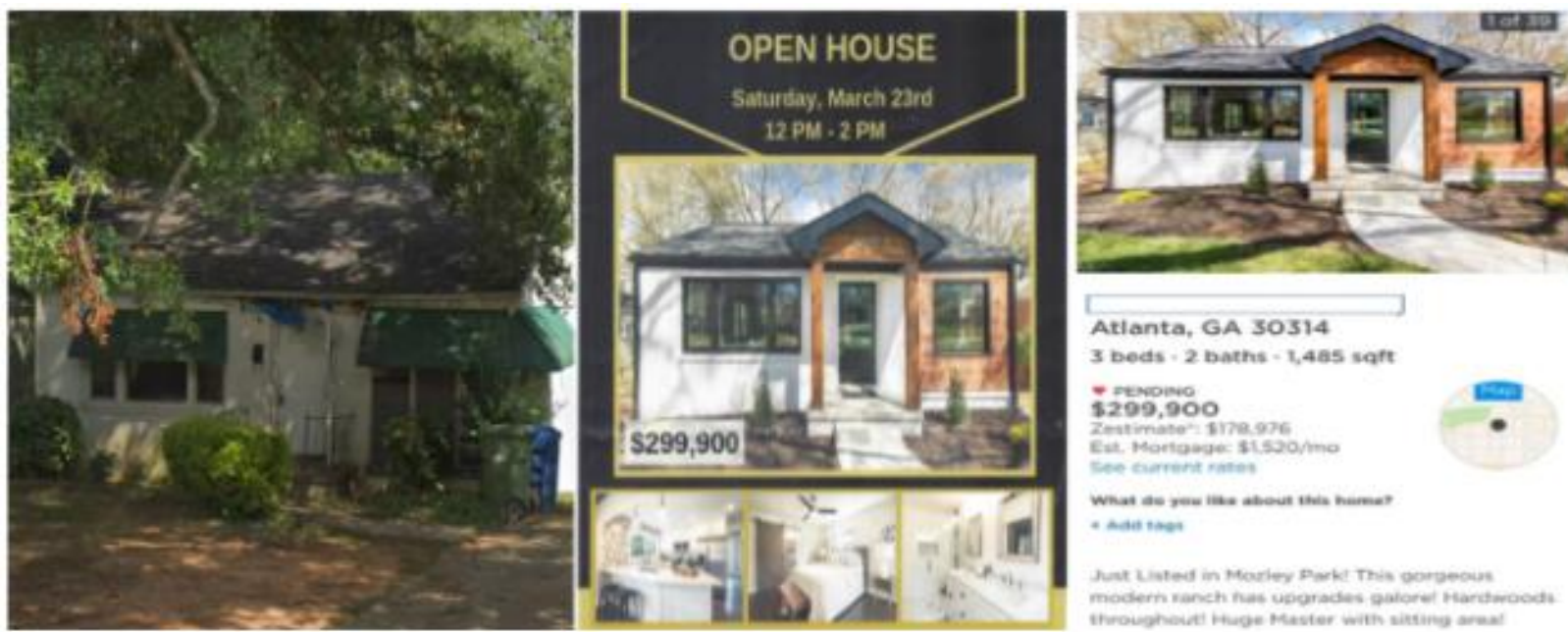

Note: Source: Left, Shae's personal photo; Middle: Realtor's Open House Flyer; Right: Zillow Group

Shae is a homeowner who intentionally purchased a home in a historically Black Southwest Atlanta neighborhood. One of her main goals was to reinvest in her community and maintain the connections and networks similar to those developed in her great-grandmother's home. Unfortunately, the relentless predatory investors have followed her. Shae is bombarded with phone calls, text messages, mailers, and even knocks on her door by investors looking to capitalize on the urban appeal and amenities of her home. Investors are constantly propositioning her to sell her house as if her Blackness is not welcomed or part of the "appeal" of the neighborhood. Shae explained,

Now that I have my own house in the city of Atlanta, not very far from my childhood Mozley Park neighborhood, I am starting to feel the sense of security and consistency that I felt in my great-grandmother's home. However, I am also starting to feel as if my presence in my neighborhood is not wanted. A few months after 
moving into my home, I received a knock on the door from a couple of White people inquiring about whether I was looking to rent my house out. They claimed they saw a posting online and were interested in touring the house. While I thought it was weird, I put no extra thoughts or energy into the occurrence. But, the first time I got a letter from a realtor to discuss options for selling my house, I was completely shocked. She wrote about how my house was in a desirable location and there were many people interested in the neighborhood and everything it has to offer. What made her think that I did not know the value of my home or the desirability of my neighborhood? Why wasn't I worthy enough to stay in my home and add to the appeal of the neighborhood? The letters and phone calls did not stop after that one. Just recently, I received an unsolicited text message that read, "Hello! My name is [redacted]. Me and my brother own an investment company called [redacted] and we were wondering if you are interested in selling the property of which you have just gained ownership. So if you want to make some fast and lucrative cash [sic] message or call me back at this number or contact one of us on our main line [sic] (see Figure 3).

\section{Figure 3}

Text Message from an Unsolicited Investor

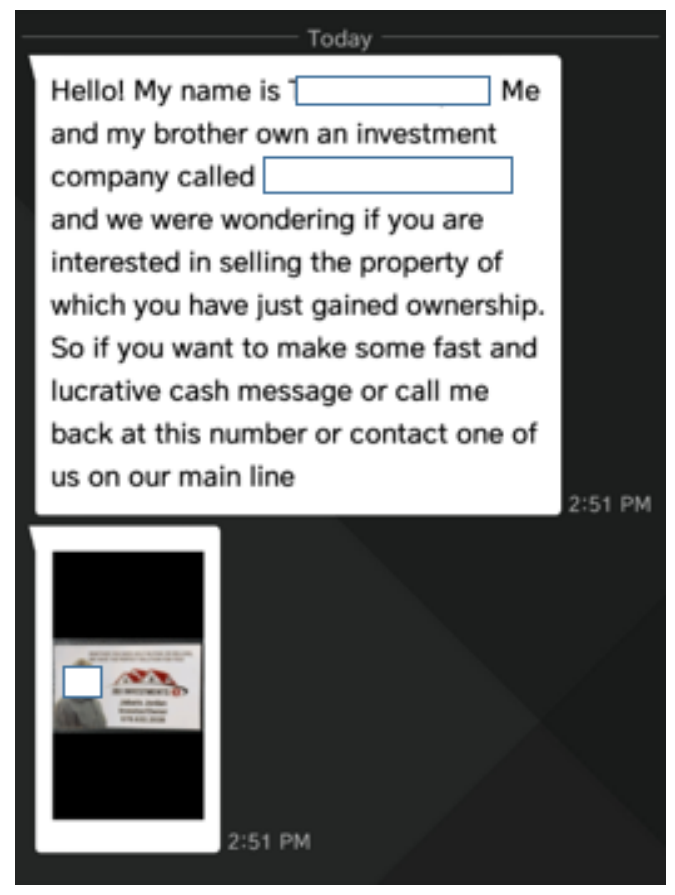

Part III: Teachers at the Center as the Connective Tissue amidst Displacement

Our research collective and comradery propel our individual fights. Our research has not only sharpened our collective understanding of displacement in schools and communities but 
also emboldened our individual resolve to fight displacement where it shows up. We have dedicated this section to the ways in which our lives are the connective tissue amidst displacement and how we fight as teachers at the center.

Rebecca earned a promotion to Assistant Principal of K-8 Literacy at a highly gentrified public charter school in Atlanta. However, Rebecca uses her knowledge and critical consciousness to ensure that the quality of instruction and needs of the remaining Black, lowincome students do not get lost to the demands of the new students and parents. Rebecca ensures that her students have normalcy and stability through their curriculum and instruction as she places high expectations on teachers to provide rigorous and equitable instruction to all students. She works daily to ensure teachers have the skills to teach students whose families have endured multiple years of neglect and disinvestment and begs them to imagine what it must be like to watch the city of Atlanta undergo rapid changes geared toward new residents moving into the neighborhood. Rebecca's efforts ensure that students have a relevant and equitable educational experience and sense of community in their classrooms when they show up to school each day.

Shakale is the mother of three children. Her goal is to ensure both her children and her students have access to quality instruction, safe and affordable housing, and equitable opportunities. Keeping this goal front and center, Shakale often serves as our eyes and ears in grassroots efforts and regularly attends community meetings on the topic of residential displacement. She also looks for economic mobility options to share with her students' parents, whether it be homeownership opportunities, down-payment assistance, or affordable home loans. Her goal is to keep parents in communities and students grounded at her school. Shakale works for a charter school organization that not only took over neighborhood schools, but also owns and operates housing developments in the area. To explain that the "affordable" housing in the area was no longer accessible to students, she often emailed the chief executive officer of the charter management organization and has attended several meetings with him on the topic. Shakale also led her peers in unabashedly and unapologetically petitioning her charter management organization to provide housing incentives for teachers. Shakale's efforts prompted the charter management organization to send an invitation to faculty and staff, inviting them to attend a neighborhood housing tour.

Thais helps our collective by bridging theory with practice. As a graduate researcher, she ensures that our voices are not invisible. She is a veteran educator and has experienced firsthand how teachers are silenced by their sociopolitical and socioeconomic pursuits. Thais introduces our collective to academic and grassroots spaces and provides teacher perspectives, experiences, expertise, and solutions where they are often missing. In these spaces, we have met with realtors and investors to discuss housing opportunities for students and families. We have presented our research in multiple venues with other educators, policymakers, and community members. Through exchanging knowledge with these stakeholders, we highlight how urban education reform and gentrification in Southwest Atlanta displaces Black students, Black families, and Black teachers. 
Shae, a native of Southwest Atlanta and product of the Atlanta Public School system, purposely chooses to teach in neighborhoods much like the one from her childhood. She embodies what it means to be a community-centered teacher by also choosing to live in her school community and finding ways to connect with families outside of school. Because she attributes so much of her success to the close bonds she had with teachers growing up, Shae understands the importance of continuing this tradition of relationship building and mentorship with her students. Shae understands firsthand the importance of housing stability to a student's well-being and future success. The fight to protect one of her own students and mentee from displacement hit Shae close to home:

Denice (pseudonym) was an extremely intelligent and outgoing child. The middle child of seven, she was extremely social and knew how to navigate her way through any space. As a student in my third-grade class during my first year of teaching, Denice was determined to take over. As she walked in my classroom with her long colorful socks and matching hair bow, she slowly looked me up and down before ignoring my instructions to come in quietly, find a seat, and begin working on the "All About Me" survey on student desks.

Despite what seemed like her attempt to completely take over the classroom, by the end of the school year, Denice and I built an extremely strong relationship. One day, I asked her if she would like for me to be her mentor. We discussed what it meant to have a mentor and she happily agreed. After speaking with her mother about it, Denice was officially attached to me forever.

Fast-forward to seventh grade. Denice and I still have a strong mentor/mentee relationship. I take her out, she spends time at my house with me and my family, and I assist her mom with getting her what she needs for school. One evening, I got a phone call from her mother. "Hey, I don't know if Denice has been telling you what is going on, but I wanted to know if she could stay with you for a few weeks. We have been living in filthy conditions. We have rats and the plumbing is coming up through the floor. We can't use the toilets or take a shower. Now the city is condemning our house and they are giving us a week to leave." As her mom went on about how their landlord was neglectful and refused to make any repairs, I could not help but to think about how Denice's life and the life of her six siblings was about to be completely disrupted.

I couldn't sulk for long as I quickly jumped into survival mode. My family and I successfully transferred Denice to the school in my neighborhood, went to court to assign me as her legal guardian, and did everything we could to make her transition to my home as effortless as possible, including allowing Denice to pick out paint 
colors for her very own room. She mentioned that she had never had her own room before. Unfortunately, the transition was far from effortless. What I soon learned was that despite the connection we had, Denice was missing the security and safety that she felt in her own home with her mom, siblings, and grandparents. Even though her house was considered unlivable, her home and network of family and friends in her neighborhood gave Denice the stability and connectedness she needed to not only survive but thrive.

Shae's story is much like all of our stories: doing whatever it takes to attend to and address the basic needs of our students. Shae's experience is just one of the many ways our professional lives are the connective tissue in our long-neglected communities. This story also shows how we use all of our resources to fight displacement. When we signed teaching contracts, we knew that our instruction would be impactful, but we did not know how far our professional lives would extend beyond the classroom walls. Our students deserve better. Our students deserve safe and affordable housing, quality education, and access to equitable opportunities. Not only do we stand in the gap that race-based policies and poor leadership have created, but we also pull out all stops to maintain their humanity and dignity as Black students.

\section{Conclusion}

While urban education reform and gentrification have rapidly spread across American cities, Atlanta provided a blueprint for removing a perceived culprit: Black teachers. There were many public-school systems with evidence of cheating, but none went to the extent of publicly indicting, trying, and sentencing Black teachers in the way that Atlanta did. This public reprimand made it palatable for Atlanta to turnover, or sell the city, to those looking to capitalize on decades of underfunding, high-stakes testing, disinvestment, and sociopolitical failures.

A federal judge declared Black educators as unfit to teach and lead Black students when he wailed that they did not take responsibility for their children. His words implied that Black teachers did not care about kids or their communities. Throughout this article, we share a myriad of ways in which we, as Black and social justice educators, not only take responsibility for our students and communities but work tirelessly to create our neighborhoods and schools in an image we would like to achieve. We employed a Critical Studyin' for Human Freedom framework through our participatory action research in Southwest Atlanta communities, and ultimately added a different but necessary voice in the fight against displacement.

Economic inequality and the absence of wealth-building opportunities for Black families shape how students show up in schools, begging Atlanta residents and officials to ask: How are we showing up for students? How will we support the aspirations of our students when housing is unaffordable, and job prospects are unpromising? How are we, as Atlanta residents, taking responsibility for student achievement while teaching students to commit to and serve a city that increasingly marginalizes them? We attempted to respond to these questions through our PAR 
process. In our roles as teachers and advocates, we are finding ways to push back against urban education reform, gentrification, and displacement.

We have invested many hours, much effort, and personal learning into understanding how gentrification and urban education reform results in the displacement of children in Southwest Atlanta. We personally experience gentrification daily as our neighborhoods, schools, and retail options have shifted to cater to more affluent, Whiter residents. Our work stands in stark contrast to the narrative that has been blared nationally about Black, urban teachers in Atlanta.

We have detailed the complex housing, and educational challenges students and families face in Southwest Atlanta. The Atlanta BeltLine has brought new residents to Southwest Atlanta and shaped uncertain paths for long-standing residents and students. Urban education reform offers more of the same educational inadequacies, but with new teachers and new buildings. The voices of community-centered teachers should not have to be forced into education and housing decision making circles, but rather invited. Our work highlights the need for a complete paradigm shift in how we value teachers and how those in power make decisions for our students. More importantly, our presence and research set a precedence for the kind of work in which our city and school leaders should be engaged. Educators should be leading work and creating scholarship that bridges gaps, nurtures, and advocates for an authentic inclusion of longstanding residents. This shift would help to build a future that ensures equitable access to education and housing that does not uproot Black students, families, and teachers from their networks and community.

Our PAR collective operates through a "double aim," where we are both students and researchers. This process has been very revealing for us personally and professionally. Our studies have revealed that there is a need for teacher voice in policymaking. Our goal is to continue to shape our own understanding as teacher leaders and to continue to raise the issues affecting the students and communities we serve. As community-centered teachers, we are morally obligated to ensure our students' needs are addressed in and out of the classroom. Our experience also revealed the urgency for our work, our right to be present, and the need for Critical Studyin' for Human Freedom. We see our students, parents, and communities as humans with deep culture and rich traditions worth preserving. We see our communities making a way out of no way, despite being sites where social and economic policies have long failed residents. We see ourselves as soldiers in this fight for humanity at the center of our schools and communities. 


\section{References}

Alliance to Reclaim our Schools (2015). Out of Control: The systematic disenfranchisement of African American and Latino communities through school takeovers. Retrieved from: http://www.reclaimourschools.org/sites/default/files/out-of-control-takeover-report.pdf.

Cahill, C. (2007). Doing research with young people: Participatory research and the rituals of collective work. Children's Geographies, 5(3), 297-312.

Fals Borda, O. (2001). Participatory (action) research in social theory: Origins and challenges. In P. Reason \& H. Bradbury (Eds.), Handbook of action research: Participative inquiry \& practice (pp. 27-37). Sage.

Foster, S., \& Lu, W. (2018, October 10). Atlanta ranks worst in income inequality in the U.S. www.bloomberg.com/news/articles/2018-10-10/atlanta-takes-top-income-inequality-spotamong-american-cities.

Freire, P. (1970/1993). Pedagogy of the oppressed. Bloomsbury.

Georgia Secretary of State. (n.d.). What Georgia Employer's Need to Know. https://sos.ga.gov/index.php/corporations/what_georgia_employers_need_to_know\#: $\sim$ :text=Georgia\%20recognizes\%20the\%20doctrine \%20of,is\%20not\%20an\%20illegal $\% 20$ cause.

Gravel, R. (2005). Addendum to BeltLine - Atlanta: Design of infrastructure as a reflection of public policy. Georgia Institute of Technology, Atlanta, GA. Retrieved from: https://smartech.gatech.edu/bitstream/handle/1853/7400/Beltline_2005 addendum.pdf? sequence $=2$ \&is Allowed $=\mathrm{y}$

Holliman, I. (2008, June 20). Techwood Homes. Retrieved from: https://www.georgiaencyclopedia.org/articles/arts-culture/techwood-homes

Housing Justice League and Research Action Cooperative. (2017). BeltLining: Gentrification, broken promises, and hope on Atlanta's Southside. Atlanta, GA. Retrieved from: https://static1.squarespace.com/static/59da49b712abd904963589b6/ t/59dedb75f7e0ab47a08224b5/1507777424592/Beltlining+Report+$+\mathrm{HJL}+\mathrm{and}+\mathrm{RA}+\mathrm{Oct}+9$. pdf

Keenan, S. (2019, June 11). In diverse metro Atlanta, why are less than a quarter of the homes black-owned? Retrieved from: atlanta.curbed.com/2019/6/11/18660452/metro-atlantablack-african-american-homeownership

King, J. E. (2006). "If justice is our objective": Diaspora literacy, heritage knowledge, and the praxis of critical studyin' for human freedom. Yearbook of the National Society for the Study of Education, 105(2), 337-360.

Lareau, A., \& Goyette, K. (2014). Choosing home, choosing schools (Project Muse). Russell Sage Foundation.

Lartey, J. (2018, October 23). Nowhere for people to go: Who will survive the gentrification of Atlanta? Retrieved from: www.theguardian.com/cities/2018/oct/23/nowhere-for-people-togo-who-will-survive-the-gentrification-of-atlanta

Matsuda, M. (1995). Looking to the bottom: Critical legal studies and reparations. In K. Crenshaw, N. Gotanda, G. Peller \& K. Thomas (Eds.), Critical race theory: The key writings that form the movement (pp. 63-79). New York Press.

McTaggart, R. (1997). Guiding principles for participatory action research. In R. McTaggart (Ed.), Participatory action research: International contexts and consequences (pp. 25-43). SUNY Press.

Morris, J. E., \& Moore, C. R. (2009). Why study the U.S. South? The nexus of race and place 
in investigating Black student achievement. Educational Researcher, 38(1), 21-36.

Niesse, M. (2014, March 29). Likely Atlanta schools chief had rocky road in Texas. Retrieved from:www.ajc.com/news/local-education/likely-atlanta-schools-chiefhad-rocky-road-texas/ADp6Kk2pXjGetb69TGewwI/

Office of Governor Nathan Deal. (2015, February 11). Deal unveils Opportunity School District legislation [press release]. https://nathandeal.georgia.gov/press-releases/2015-02-11/dealunveils-opportunity-school-district-legislation

Robinson, S., \& Simonton, A. (2019). None of the above: The untold story of the Atlanta Public Schools, cheating scandal, corporate greed, and the criminalization of educators. Beacon Press.

Royal, C., \& Seriki, V. D. (2018). Overkill: Black lives and the spectacle of the Atlanta Cheating Scandal. Urban Education, 53(2), 196-211.

Stapleton, S. R. (2018). Teacher participatory action research (TPAR): A methodological framework for political teacher research. Action Research. https://doi.org/10.1177/1476750317751033.

The Governor's Office of Student Achievement. (2017). Student mobility rates by school and district.

Vale, L. J. (2013). Purging the poorest: Public housing and the design politics of twice-cleared communities. University of Chicago Press.

Valenzuela, A. (Ed.). (2016). Growing critically conscious teachers: A social justice curriculum for educators of Latinola youth. Teachers College Press. 